\title{
KOMPARACIJA TURISTIČKIH SCENARIJA RAZVOJA POVALJA NA OTOKU BRAČU 2009. I 2019.
}

\author{
Jelena Zlatar Gamberožić i Anđelina Svirčić Gotovac
}

\author{
Institut za društvena istraživanja u Zagrebu \\ Frankopanska 22, 10000 Zagreb \\ e-mail: zlatar.jel@gmail.com
}

\begin{abstract}
Sažetak
Socioprostorne transformacije u Hrvatskoj obuhvaćaju gradove $i$ sela, kako na kopnu tako i na otocima. Vodene su interesima različitih društvenih aktera pri čemu prostor intervencije doživljava različite promjene kako u svojoj socijalnoj strukturi tako i u okolnom prostoru. Na otocima koji su danas izloženi negativnim demografskim procesima depopulacije i gubitka stanovništva, dodatno je otežano pokrenuti razvoj ili omogućiti pozitivne promjene. U tome se ističu upravo najmanji otoci i manja naselja na njima kao što je primjer naselja Povlja na Braču. U radu će se prikazati studija slučaja kao komparativna longitudinalna analiza ovog mjesta i promjene koje su vidljive u istraživanjima provedenima u razmaku od deset godina (2009. i 2019.). Cilj je istraživanja usporediti jesu li se potencijalni turistički scenariji razvoja za Povlja iz 2009. (masovni turizam, održivi turizam $i$ stagnacija) promijenili u ovom vremenskom razdoblju s obzirom na socijalnu i ekonomsku situaciju. Metodom polustrukturiranih intervjua sa stalnim i privremenim (sezonskim) stanovnicima Povalja istražilo se promišljanje stanovnika o trenutnom i potencijalnom turističkom razvoju mjesta, te koliko se istraživanje iz 2009. može usporediti s rezultatima istraživanja iz 2019. Istraživanje iz 2019. pokazalo je da mjesto nije napredovalo ni u turističkom ni u ekonomskom smislu, $i$ da je od ponudenih scenarija najprisutniji scenarij stagnacije koji prelazi i u nazadovanje.
\end{abstract}

Ključne riječi: manja otočna naselja, turistički scenariji razvoja, turizam, Povlja, Brač

\section{UVOD}

Jadranski otoci, kao i njihove turističke odrednice i potencijali, važna su istraživačka tema mnogih autora posljednjih desetljeća (Starc, 1994; Šimunović, 1994; Starc, 2001; Kuvedžić, 1999; Defilipis, 2001; Radinović i sur., 2004; Starc i Stubbs, 2007; Petrić i Pranić, 2010; Mackelworth i Carić, 2010; Podgorelac i Klempić Bogadi, 2013; Lajić i Mišetić, 2013a; Tonković i Zlatar, 2014; Zlatar Gamberožić i Tonković, 2015 i dr.) pogotovo zbog različitih promjena u društvu u vremenu tranzicije, a s obzirom na ulogu socioprostornih aktera (ekonomskih, profesionalnih, političkih i civilnih). Hrvatski se otoci često smatraju indikatorom onoga što se događa u unutrašnjosti (Magaš, 1996), na kopnu, a njihova se problematika najvećim dijelom tiče negativnih demografskih trendova vidljivih u depopulaciji i senilizaciji stanovništva (Fabjanović, 1991; Lajić i sur., 2001; Friganović, 2001; Graovac, 2004; Mišetić, 2010; Klempić Bogadi i Podgorelec, 2011; Lajić i Mišetić, 2013b; Nakićen i Čuka, 2016 i dr.). U svrhu slabljenja ovih 
procesa ojačava se bavljenje turizmom, posebno onim održivog tipa, ali pri tome nerijetko dolazi do brojnih poteškoća. Razlozi su dijelom i u brzom trošenju prirodnih resursa tako da se mnogo jadranskih otoka (Hvar, Brač, Krk itd.) nalazi u situaciji iscrpljivanja svojih važnih resursa, primjerice krajolika, bez uspostavljanja čvrstih i ekološki usmjerenih turističkih temelja i razvojnih koncepata. Turizam je tako, u mnogo slučajeva, neplanski usmjeren i neosmišljen te je ostavljen parcijalnim rješenjima samih pojedinaca. Stoga je potrebno obratiti pozornost na postojeće prostorne strategije koje detaljno obuhvaćaju i nosivost (engl. carrying capacity) svakog pojedinog mjesta. Ovaj rad nastoji prikazati upravo takav jedan primjer, kroz komparativnu analizu, tj. usporedbu mjesta i njegovih turističkih kapaciteta u dva vremenska razdoblja - 2009. i 2019. s ciljem ukazivanja na turističku situaciju u ta dva razdoblja i daljnje mogućnosti razvoja. U radu ćemo se prvo orijentirati na neke ključne odrednice turizma otoka Brača kroz postojeća istraživanja, a zatim na mjesto Povlja i turistička kretanja u Povljima. Kroz komparaciju s 2009. u sljedećem poglavlju fokusirat će se na najvažnije kategorije kojima smo nastojali dati uvid u turističko stanje u Povljima. Također je važna odrednica, osim vremenske komparacije bila i komparacija u mišljenjima stalnih i sezonskih stanovnika, kao i mogućnosti daljnjeg razvoja onako kako ga oni vide. Nastojalo se i preispitati daljnje mogućnosti revitalizacije mjesta i ukazati na ključne odrednice koje treba imati u vidu pri daljnjem razvoju.

\section{OTOK BRAČ IZMEĐU STAGNACIJE, ODRŽIVOSTI I MASOVNOSTI}

Brač je najveći otok srednjodalmatinske skupine (Slika 1). Dug je oko $40 \mathrm{~km}$, širok prosječno $12 \mathrm{~km}$, a s ukupnom površinom od $395 \mathrm{~km}^{2}$ treći je otok po veličini na Jadranu. Intervencije koje je otok doživljavao u svom prostoru tiču se uglavnom intenzivne izgradnje u njegovim naseljima kao i promjenama u njegovoj socijalnoj strukturi i depopulacijskim procesima prisutnima u većini slučajeva i na drugim jadranskim otocima. „Jedan je od glavnih ciljeva u razvoju turizma na hrvatskim otocima upravo sprečavanje depopulacije otoka, pogotovo manjih ruralnih naselja na njima, u demografskoj strukturi i gospodarskoj situaciji“ (Zlatar, 2010:251). Pogotovo su depopulacijskim trendovima izložena manja ruralna mjesta u što spada većina mjesta na otoku Braču. Brač ima 13.987 stanovnika (Općina Selca, 2021), od čega najveći broj ima općina Supetar, a najmanji Sutivan (Tablica 1). Neki autori upozoravaju kako će izumrijeti čak oko $25 \%$ naselja na hrvatskim otocima i to najviše na manjim otocima bez trajektne linije i mosta, te ona mjesta koja se nalaze u unutrašnjosti otoka (Stiperski i sur., 2001).

Za takva otočna mjesta postoji mogućnost da će se transformirati iz radno-rezidencijalnoga u prostor za odmor i rekreaciju (Faričić i sur., 2010). O tome govori u prilog i smanjenje broja stanovnika od 2001. do 2011. na otoku Braču gdje je vidljiv pad od 9\% od kojih su najvećim dijelom visokoobrazovani i mladi ${ }^{1}$. Ponajviše su ugrožena manja

1 Budućnost otočnog prostora osim nepovoljnog demografskog stanja (izdvojeno je i kao područje najveće demografske regresije) opterećuje još čitav niz okolnosti. To su periferni položaj otoka, pomanjkanje spo- 
naselja poput Povalja jer su izoliranija i manje atraktivna te osjetljivija na depopulaciju i odlazak stalnih stanovnika, a sve više ovisna o sekundarnim ili sezonskim stanovnicima. Gospodarstvo otoka oduvijek se temeljilo na poljoprivredi (maslinarstvo, vinogradarstvo), stočarstvu, ribarstvu i kamenarstvu; u novije vrijeme raste važnost turizma, trgovine i usluga, te se radi o većinom tradiciji mješovitih gospodarstava (poljoprivreda, ribarstvo, industrija, turizam). Danas se važnost poljoprivrede na otocima kao djelatnosti smanjuje i ono je prisutno „i zbog smanjenja poljoprivrednih područja te danas u nacionalnom dohotku jadranskih otoka sudjeluje sa svega 13,4\%. Na otoku Braču njezin je udio 21,5\%" (Defilippis, 2001:87). Udio primarnog sektora (poljoprivrede i ribarstva), primjerice, za općinu Selca, kojoj pripada i naselje Povlja, iznosio je 2011. tek 14,45\% (DZS, 2011, prema Martinić Jerčić, 2018:8). U Povljima u posljednjem desetljeću dolazi do pronalaženja prihoda u drugim sektorima, prvenstveno turizmu.

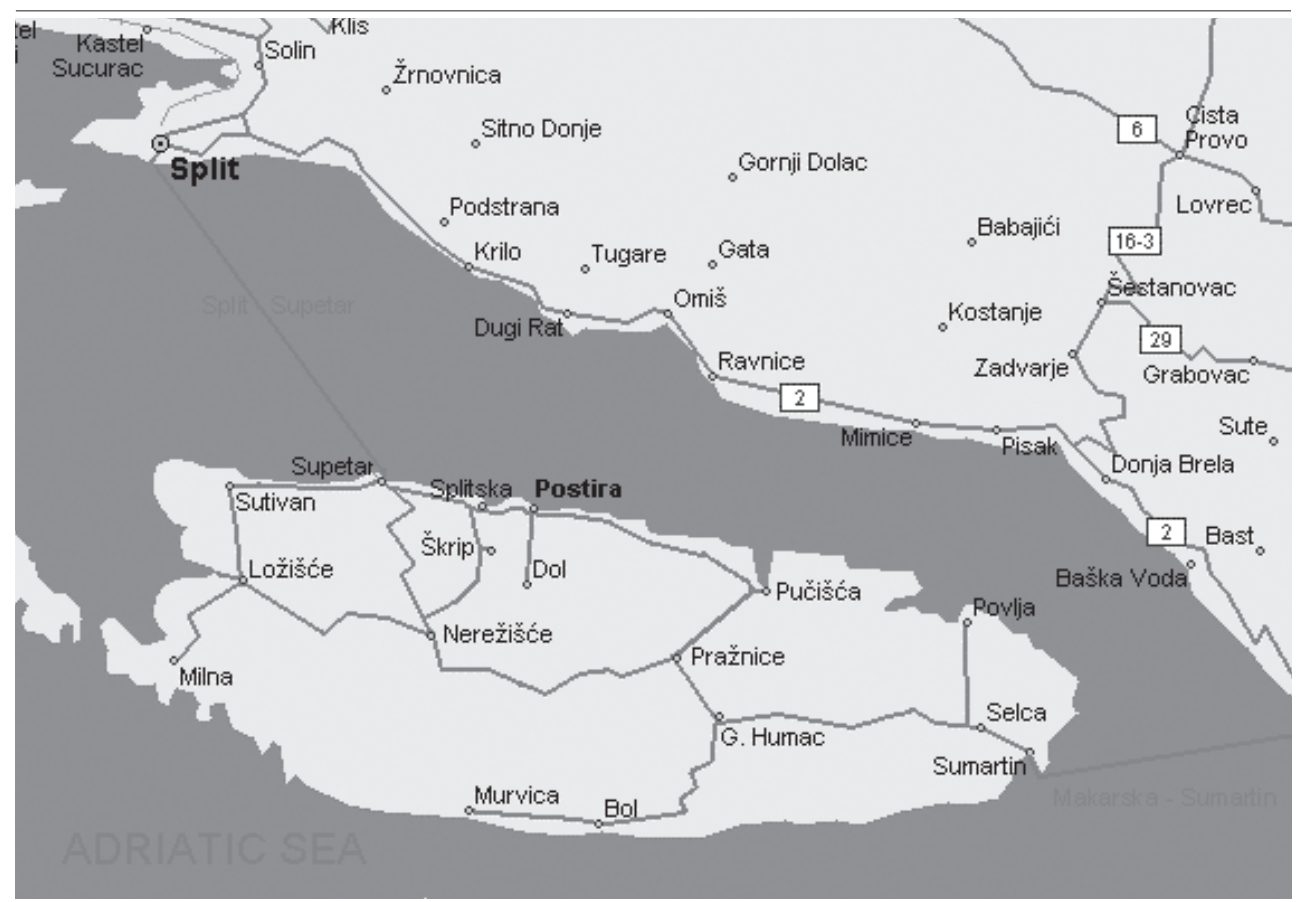

Slika 1. Položaj otoka Brača (Ruzmarin, 2020)

sobnosti lokalnih aktera i tzv. „fiktivno“ stanovništvo na otocima koje po svojoj dobnoj strukturi pripada starijoj populaciji. Do problema dolazi i kod koncentriranja gospodarstva na velike gospodarske subjekte (Zlatar, 2010:250). Inače fiktivnom porastu otočne populacije nakon 1991. pridonio je rast broja popisanih inozemnih stanovnika otoka na privremenom radu u inozemstvu te također i povećan broj tzv. vikendaša koji su se prijavljivali kao stalno stanovništvo otoka. „Dok su 1991. glavninu 'fiktivne otočne populacije’ činile osobe na radu u inozemstvu i iseljenička populacija, u popisima 2001. i 2011. u toj kategoriji prevladavaju vlasnici kuća za odmor" (Lajić i Mišetić, 2013b:171). 
Tablica 1. Stanovništvo Brača prema općinama (Općina Selca, 2021)

\begin{tabular}{|c|c|}
\hline Općina - grad & Broj stanovnika \\
\hline Supetar & 4.096 \\
\hline Pučišćca & 2.189 \\
\hline Selca & 1.804 \\
\hline Bol & 1.645 \\
\hline Postira & 1.554 \\
\hline Milna & 1.009 \\
\hline Nerežǐćca & 864 \\
\hline Sutivan & 826 \\
\hline Ukupno Brač & $\mathbf{1 3 . 9 8 7}$ \\
\hline
\end{tabular}

Turizam, kao jedna od najvažnijih gospodarskih grana na jadranskim otocima i na otoku Braču snažno se razvija od 60-ih godina, a najviše u privatnom smještaju (Kuveždić, 2001). Zajedno s izgradnjom infrastrukture, razvija se i turistička ponuda u mnogim mjestima na otoku Braču (Tablica 2). Pojedina naselja su se deagrarizirala i modernizirala te razvila model masovnog turizma (primjerice općina Bol), dok su pojedina ostala uglavnom ruralnog tipa kao i ovdje istraživano naselje Povlja. Važno je napomenuti da je organizacija lokalne samouprave u bivšoj državi izgledala tako da je cijeli otok bio jedna općina, dok je danas prisutno osam jedinica lokalne samouprave, odnosno osam općina. Prema pojedinim autorima (Starc i Stubbs, 2007; Tonković i Zlatar, 2014) postoji neformalna koordinacija čelnika među tim općinama, ali ne i zajedničko planiranje razvoja čitavoga otoka. To predstavlja veliki problem za daljnji razvoj pogotovo za ravnomjerniju raspodjelu njegovih socijalnih i ekonomskih potencijala spomenutu i u Zakonu o otocima (NN 116/18, 73/20).

Tablica 2. Dolasci i noćenja na Braču (Turistička zajednica općine Selca, 2020)

\begin{tabular}{|c|c|c|c|}
\hline Godina & Dolasci & Noćenja & $\begin{array}{c}\text { Udjel stranih turista u } \\
\text { dolascima (u \%) }\end{array}$ \\
\hline 1970. & 46.384 & 567.893 & 32,1 \\
\hline 1980. & 79.515 & 986.155 & 41,6 \\
\hline 1990. & 114.975 & 1.025 .416 & 62,6 \\
\hline 2000. & 124.198 & 781.344 & 66,4 \\
\hline 2010. & 160.200 & 1.179 .872 & 90,5 \\
\hline 2018. & 258.345 & 1.726 .063 & 91,6 \\
\hline
\end{tabular}

Prema istraživanjima o mogućnostima i tipovima turizma na otoku Braču provedenima 2009., 2013. i 2015. (Zlatar, 2010; Tonković i Zlatar, 2014; Zlatar Gamberožić i Tonković, 2015) predstavljena su tri tipa turizma i turističke ponude prisutne na otoku, a obuhvaćala su tri mjesta: Povlja, Postira i Bol. Istraživanje iz 2015. (Zlatar Gamberožić i Tonković) fokusiralo se na razlike u pristupu prema masovnom ili održivom turističkom razvoju u ta tri mjesta: a) Povlja, u kojima je naglasak na razvoju eko-turizma i turizma 
malih razmjera koji bi se mogao osmisliti kroz oprezno planiranje i restrukturiranje postojećih kapaciteta; b) Postira, koja su predstavljala dobar primjer kooperacije lokalne vlasti s lokalnim dioničarima vodeći računa o sve četiri dimenzije održivosti i pokušaju diversificiranja turističke ponude tako da poboljša povezanosti između turizma i ostalih sektora lokalne ekonomije i c) Bol, kao treći primjer, koji nije pokazao mogućnosti za održivi razvoj turizma koji bi doprinio smanjenju tj. redukciji broja turista tijekom sezone i očuvanju resursa okoliša. Ove tri studije slučaja pokazale su uvid u tri različite perspektive turističkog i održivog razvoja s time da se ekonomska održivost turizma pokazala važnijom od ostalih.

Turistički razvoj jadranskih otoka trebao bi biti usmjeren ponajprije prema održivom razvoju (Dodds, 2007; Farsari i sur., 2007; Wiles Howard, 2001) i ekoturizmu te se odvijati kako u skladu jedan s drugim, tako i s ostalim gospodarskim granama prisutnima na otoku (Zlatar, 2010:252). Smatra se kako gospodarstvo otoka također ne bi trebalo razdvajati na poljoprivredno, industrijsko i turističko već ih objediniti (Šimunović, 2007) te usmjeriti ka izgradnji turističkog identiteta otoka prepoznatljivog i na tržištu. Mješovitost tipova djelatnosti stoga se može i dalje smatrati važnom komponentom budućeg razvoja otočkih naselja, ali vodeći se u svakoj od njih smjernicama održivog razvoja. I u Zakonu o otocima (NN 116/18, 73/20) među najvažnijim ciljevima prisutni su održivost i održivi razvoj:

\subsection{Povlja na otoku Braču}

Naselje Povlja (Slika 2) spada pod općinu Selca koja se sastoji još od naselja: Selca, Novo selo i Sumartin. Istraživanja su pokazala kako su Povlja zadržala odrednice ruralnog tipa naselja (izvorne ruralne arhitekture i autohtonog agrarnog krajolika, kao i vrlo slaba naseljenost i pretežno niske razine tehničke i komunalne infrastrukture) (Zlatar, 2010). Kao jednom od najmanjih mjesta na otoku Braču u 20. stoljeću nakon Prvog svjetskog rata u Povljima, kao i u ostalim bračkim mjestima, počinje opadati broj pučanstva. Opadanje broja stanovnika vidi se i u dva zadnja popisa stanovnika te su prema popisu stanovništva iz 2001. Povlja imala 363 stalna stanovnika (Zlatar, 2010), a prema Popisu iz 2011. 319 stanovnika (DZS, 2011) što je pad za $8,8 \%$. Stanovnici se većinom bave ribarstvom, uzgojem maslina, proizvodnjom vina i ove se aktivnosti prenose iz generacije u generaciju. Infrastrukturno su prisutni različiti problemi, pogotovo problem nedovoljnih pristupnih cesta i parkirališnog prostora za prihvat automobila kojima se dolazi na otok što usporava razvoj turizma.

Godine 1960. u naselje je uvedena elektrifikacija, 1970. vodovod, 1980. asfalt, 1990. telefon, a tek 2000. sistem odvodnje ili kanalizacije.

2 Neke od ključnih dimenzija u Zakonu su: (1) Održivi razvoj otoka pretpostavlja ostvarivanje općih ciljeva: stabilan gospodarski razvoj otoka, pravednu raspodjelu socijalnih mogućnosti za sve otočane, zaštitu otočnog okoliša i povećanje otpornosti na klimatske promjene. (2) Poticanje ulaganja u konkurentne i inovativne sektore koji su ekološki, prostorno, gospodarski, tehnološki i društveno održivi (NN 116/18, $73 / 20)$ 


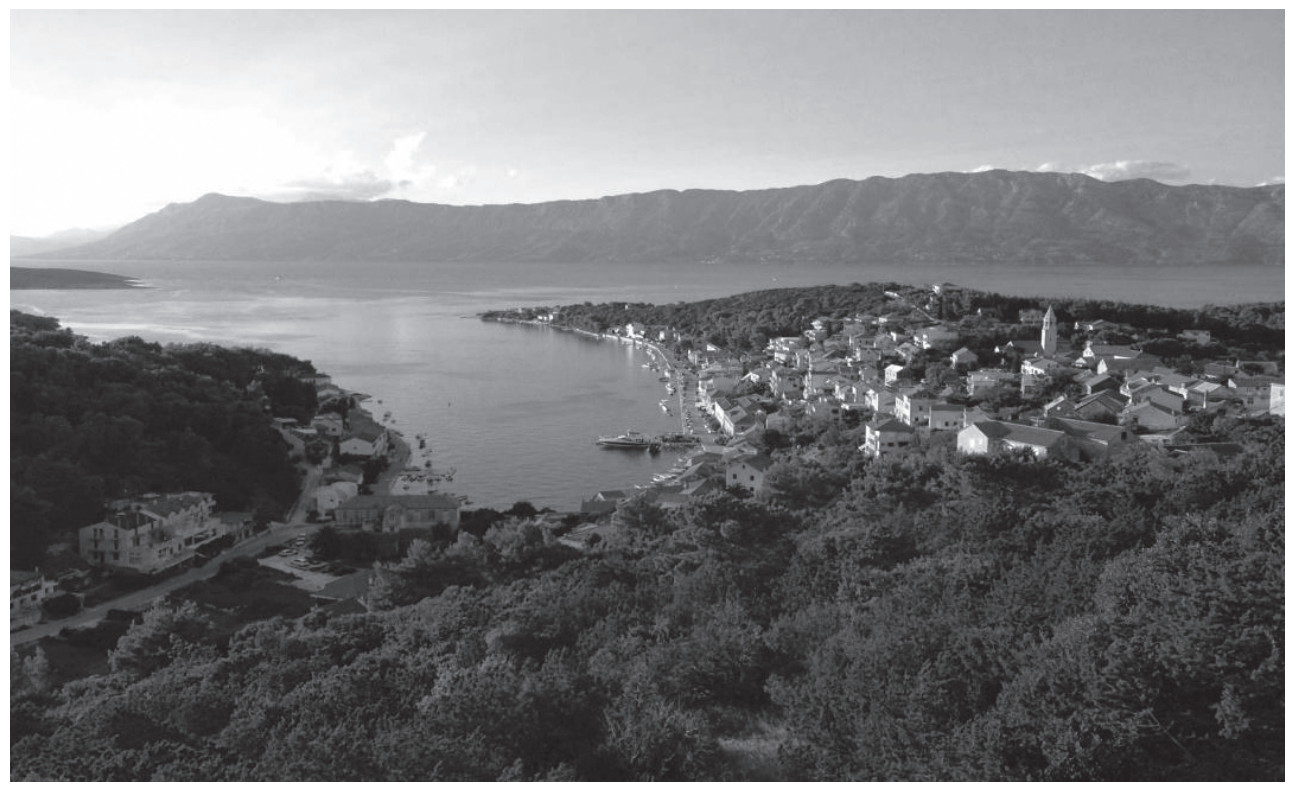

Slika 2. Naselje Povlja na otoku Braču (fotografija autorica, 2019)

Turistička kretanja u Povljima (Tablica 3) ovisna su o mnogim faktorima, ponajprije ratnim zbivanjima od 90-ih naovamo kad dolazi do naglog pada broja gostiju. Inače je broj gostiju rastao od 26 osoba 1960. do 3.522 osobe 1980., a zatim počeo padati. Slična je situacija i s brojem noćenja, koji je imao svoj vrhunac u desetljeću od 80-e do 90-e da bi zatim počeo padati. Godine 2000. bilo je najmanje gostiju (933) i najmanji broj noćenja (9.981). Nakon 2000. turistička djelatnost oživljava i 2004. broj gostiju dosegao je 1.938 gostiju, a broj noćenja 14.194. Godine 2017. i 2018. broj noćenja porastao je na 42.870 odnosno 46.262 (2018.) i u odnosu na prošla desetljeća bilježi sve veći broj dolazaka i to većinom stranih turista. Osjetan pad turizma u razdoblju do 2000. možemo pripisati i činjenici da je u zadnjih 20-ak godina hotel Galeb (Slika 3) ugasio svoje poslovanje, što se negativno odrazilo na čitav turistički razvoj naselja. Privatni je smještaj jedna od osnovnih investicija u turizmu Povalja i raste iz godine u godinu, tako da je ponuda smještaja od 12 kreveta koliko je imao 1960. do 2004. porastao na 674 i 2018. na 1.036 (Turistička općina Selca, 2019).

Tablica 3. Turistički promet Povalja (Vlahović, 2007:209; Turistička zajednica općine Selca, 2020)

\begin{tabular}{|c|c|c|}
\hline Godina & Broj dolazaka & Broj noćenja \\
\hline 1960. & 26 & 300 \\
\hline 1965. & 1.330 & 14.044 \\
\hline 1970. & 1.000 & 12.000 \\
\hline 1980. & 3.522 & 27.007 \\
\hline 1990. & 3.000 & 25.000 \\
\hline
\end{tabular}




\begin{tabular}{|c|c|c|}
\hline 2000. & 933 & 9.981 \\
\hline 2003. & 1.648 & 11.194 \\
\hline 2004. & 1.938 & 14.194 \\
\hline 2014. & 2.530 & 22449 \\
\hline 2017. & 4.337 & 42.870 \\
\hline 2018. & 4.794 & 46.262 \\
\hline
\end{tabular}

Proces privatizacije nekadašnjih državnih turističkih nekretnina u mjestu (hotel Galeb i apartmani Punta) veže se uglavnom uz jednog vlasnika čime je utjecaj lokalnog stanovništva na njih značajno marginaliziran. Međutim, $s$ druge strane pozitivna je činjenica da su društveni i ekonomski akteri koji bi potakli razvoj svjesni važnosti okoliša koji predstavlja pozitivan primjer očuvanosti teritorijalnog identiteta budući da nije došlo do razvoja masovnog turizma niti masovne izgradnje (procesa apartmanizacije i betonizacije). Samo takve vrste turizma su i poželjne (eko-turizam, agroturizam) jer vode računa o turističkim kapacitetima Povalja (Zlatar, 2010; Zlatar Gamberožić i Tonković, 2015). Mjestu je potrebna inkorporacija u nove razvojne tendencije koje će revitalizirati njegove ekonomske, kulturne i socijalne dimenzije. Istraživanje iz 2009. pokazalo je velike potencijale koje mjesto Povlja ima u poljoprivrednom smislu, kako u prirodnim resursima, tako i u krajoliku, no ti potencijali nisu bili iskorišteni na uspješan način. Također, u tom su razdoblju prije desetak godina planovi za razvoj turizma u Povljima bili usmjereni prema glavnim točkama investiranja, hotelu Galeb i apartmanskom naselju Punta, ali i ostalim potencijalnim lokacijama - Tičja luka, Riva te uvala Luke (Zlatar, 2010:259).

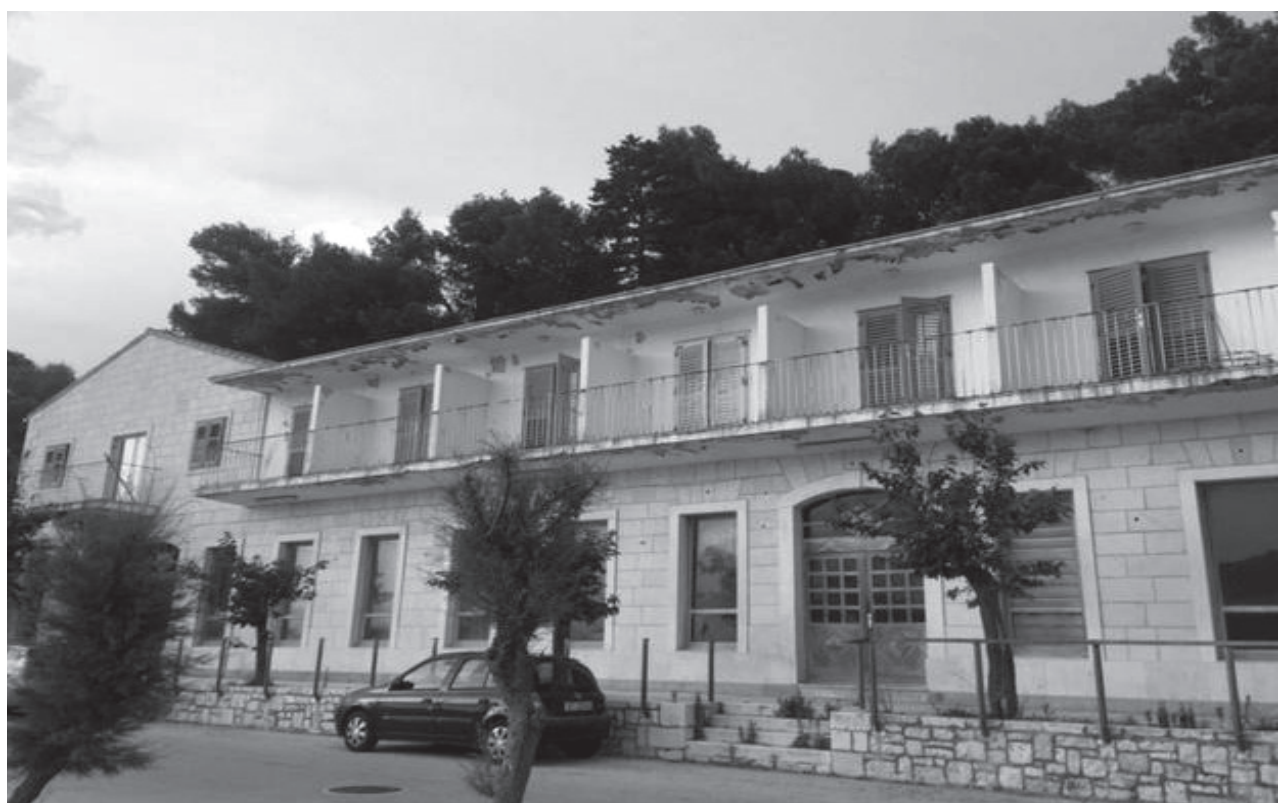

Slika 3. Zatvoreni hotel Galeb (fotografija autorica, 2019) 


\section{METODOLOGIJA ISTRAŽIVANJA}

Korištena metoda studija slučaja temeljila se na komparativnoj longitudinalnoj analizi istraživanog naselja. Obuhvatila je analizu dokumentacije i statističkih podataka iz Popisa stanovništva te ranije provedeno kvalitativno istraživanje $s$ polustrukturiranim intervjuima. Intervjui su u prethodnom i ovom istraživanju provedeni s ključnim akterima lokalnog razvoja. U njima su sudjelovali akteri iz različitih sektora djelatnosti kao što su lokalna politika, turizam, poljoprivreda i kultura te zaposleni u lokalnoj samoupravi i turističkoj zajednici, zatim vlasnici apartmana, ugostitelji, hotelijeri, obrtnici, maslinari i akteri u kulturi (poput organizatora izložbi, priredbi i sl.) s kojima je ukupno obavljeno trideset polustrukturiranih intervjua ${ }^{3}$. Dobiveni podaci komparirani su s istraživanjem iz 2009. koje se također bavilo tematikom razvojnih potencijala (Zlatar, 2010) pri čemu se nastojalo istražiti i komparirati nastale promjene te aktualnost prijašnjih rezultata. Longitudinalna analiza sociološki može biti definirana na više načina, između ostalog i kao prikupljanje različitih podataka u dva različita vremenska razdoblja, kao i istraživanje istog slučaja i prikupljanje istih podataka u dva različita vremenska odsječka (Ruspini, 1999:223) što je slučaj u ovom radu.

Hipoteza istraživanja jest da se stanje u naselju Povlja u smislu turističkog razvoja nije u velikoj mjeri promijenilo te je i dalje prisutna stagnacija kao jedan od tipova scenarija dobivenog istraživanjem iz 2009. Ciljevi istraživanja bili su komparirati stanje iz 2009. s onim iz 2019. s obzirom na ponuđene scenarije kao i ostale kategorije izvedene iz intervjua. Usporedba se odnosila na stalne i sezonske stanovnike odnosno na koji način oni doživljavaju eventualne promjene i sadašnju situaciju.

U analizi se koristila jednaka kategorijalna shema intervjua kao u 2009. koja se sastojala od sljedećih elemenata: Trenutno stanje turizma u Povljima; Prednosti i nedostaci turizma u Povljima; Glavne turističke lokacije i atrakcije; Glavni akteri / pokretači turizma; Tip / reputacija turizma; Perspektive i mogući scenariji razvoja turizma. Kroz intervjue također su istražene i ideje sugovornika za daljnje poboljšanje turizma koje su ispitane i kategorizirane u četiri ključne kategorije. Istraživanje je provedeno u lipnju i kolovozu 2019.

Korištenje iste kategorijalne sheme bilo je potrebno prvenstveno zbog istraživanja provedenog u dva vremenska razdoblja, budući da je istraživanje iz 2009. naznačilo moguće pravce razvoja (scenarije) koji su ovom analizom zatim i provjereni. Kroz komparaciju različitih odgovora sugovornika moglo se istražiti u kojoj su mjeri pozitivne i negativne strane turizma i dalje prisutne, je li se stanje (i ako je, kako) promijenilo u posljednjih desetak godina, ali i uvidjeti koliko su se stavovi sugovornika promijenili te kakav je njihov pogled na razvoj turizma danas.

3 Radilo se o kombinaciji intervjua sa sezonskim (13) i stalnim stanovnicima (17) različitih dobi (iznad 30 godina starosti) i zanimanja (konobari, prodavači, umirovljenici, inženjeri, profesori, turistički radnici, psiholozi, muzikolozi, bivši načelnik općine i nezavisni općinski vijećnik i član turističkog vijeća). Prema školskoj spremi sugovornika podjednako ih je bilo sa srednjom is visokom stručnom spremom. 


\subsection{Rezultati istraživanja}

Kao što je vidljivo iz Tablice 4 stanje turizma u Povljima 2009. pokazalo je mnogo neiskorištenog potencijala, što je predstavljalo najveći turistički problem mjesta.

Tablica 4. Stanje turizma u naselju 2009. i 2019.

\begin{tabular}{|l|l|}
\hline \multicolumn{1}{|c|}{2009.} & \multicolumn{1}{|c|}{2019.} \\
\hline Neiskorišten potencijal: „Potencijal je daleko od isko- & Povećanje privatnog smještaja: „U \\
rištenosti, prije svega jer hotel Galeb i apartmani na & privatnom sektoru smještajni kapacite- \\
Punti nisu u funkciji.“ (profesor, sezonski stanovnik) & ti su se povećali, ali u hotelskom se nije \\
Slaba turistička ponuda: „Mislim da se kvaliteta tu- & maklo s mjesta.“ (umirovljenik, stalni \\
rista pogoršala, a broj povećao. Potencijal mjesta nije & stanovnik) \\
toliko loše iskorišten za obiteljski turizam srednje i niže & Stagnacija: „Ništa se nije radilo. Već 25 \\
platežne moći. Lošije je iskorišten za goste kojima ne- & godina stagniramo po svakom pitanju. Na \\
dostaju luksuzni apartmani i restorani. “ (tour-agent, & ničemu se ne radi jer nas općina ignorira. \\
sezonski stanovnik) & (umirovljenik, stalni stanovnik) \\
"Povlja kao turističko mjesto ne nude mnogo, i nažalost & "Ne vidim neke posebne razlike odprije 10 \\
ne vidim značajniju promjenu. Sadržaja je malo i go- & godina.“ (profesor, sezonski stanovnik) \\
stima se osim mora i ponekog restorana (gdje bi ponuda & Nazadovanje: „Situacija je daleko ispod \\
mogla biti i mnogo bolja) nema što pružiti.“ (ugosti- & svih mogućih normi. “ (stolar, stalni sta- \\
teljski djelatnik, sezonski stanovnik) & novnik) \\
\hline
\end{tabular}

Problemi su vidljivi u ključnim potencijalima koji su mogli biti nositelji turizma u mjestu, prvenstveno radu hotela Galeb i apartmana na Punti. Tako su apartmansko naselje i hotel ostale glavne investicije u mjestu, kako 2009. tako i deset godina kasnije. U usporedbi s 2009. i u 2019. sugovornici navode (u skladu s ranije navedenim statističkim podacima) primjetno povećanje broja privatnog smještaja. Također, apartmansko naselje i hotel nisu stavljeni u funkciju, što mjesto, prema ocjeni sugovornika, čini i dalje obilježeno stagnacijom, ili čak nazadovanjem. Također je propitivana i turistička ponuda „mora i sunca" (Aguiló i sur., 2005; Dodds, 2007), inače često prisutna u dalmatinskim mjestima kao jedina, koja je predstavljala ograničene mogućnosti za turiste te na koju se upozoravalo kao na nedovoljno razrađenu i osmišljenu ponudu.

Što se tiče prednosti i nedostataka turizma u Povljima (Tablica 5) može se primijetiti da se 2009. i 2019. pojavljuju slični odgovori kod sugovornika.

Tablica 5. Prednosti i nedostaci turizma u 2009. i 2019.

\begin{tabular}{|l|l|}
\hline \multicolumn{1}{|c|}{ 2009. i 2019. - PREDNOSTI } & 2009. i 2019. - NEDOSTACI \\
\hline $\begin{array}{l}\text { Netaknuta priroda i čisto more: „Pozitivne stra- } \\
\text { ne Povalja su ljepota samoga mjesta: netaknutost } \\
\text { prirode, čistoća mora i lijepe plaže.“ (profesorica, } \\
\text { sezonski stanovnik) }\end{array}$ & $\begin{array}{l}\text { "Sože se više no slab je interes i tako je već 20- } \\
\text { mo turizam: „Problem je što se sve } \\
\text { ak godina." (ugostitelj, sezonski stanovnik) }\end{array}$ \\
\hline
\end{tabular}




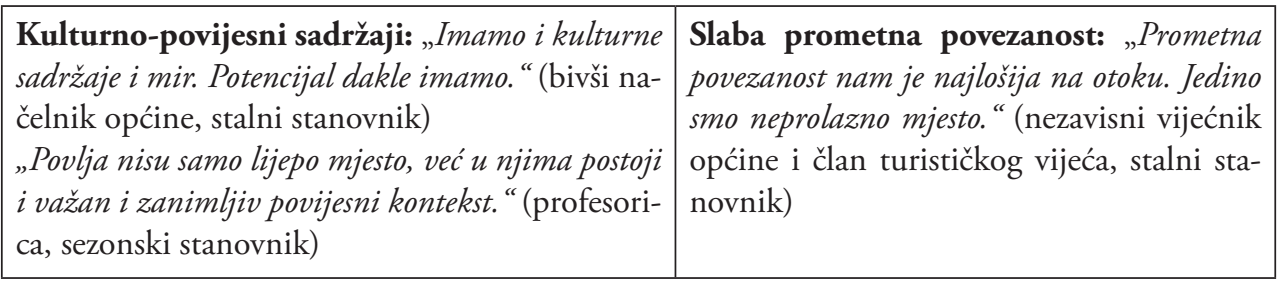

Prednosti se uglavnom odnose na čistu i netaknutu prirodu, povijesne spomenike, gastronomsku ponudu i sportske sadržaje (naročito 2019. kada je otvorena sportska dvorana u središtu mjesta). Nedostatke možemo dijelom podvesti pod tzv. „stihijski turizam“ (Delibašić i Vidučić, 2003; Šulc, 2014) koji se uglavnom vide u nesustavnoj i neorganiziranoj turističkoj ponudi. Tome svakako doprinosi i demografska slika naselja jer, mlađe stanovništvo, iseljava, često i za stalno. Ostali problemi koji se spominju u prvom su redu loša prometna povezanost na čitavom otoku, pri čemu nekoliko autobusnih linija između glavnih mjesta dobro funkcionira, dok ostatak, pogotovo manjih mjesta poput Povalja, unatoč formalnom rasporedu često nemaju utvrđeni red vožnje. Visoke cijene gastroponude su također istaknute kao problem, kao i neuređene i neočišćene plaže. Velike količine komunalnog otpada u centru mjesta stanovnici također smatraju zasad nerješivim problemom kao i derutni hotel i brod koji je godinama (do 2019.) stajao potopljen u moru u samom središtu mjesta. To također osim estetskih ima i ekološke posljedice na mjesto koje kao jednu od svojih prednosti ističe upravo čist krajolik i prirodne ljepote. Neriješeni imovinsko-pravni odnosi često leže u pozadini navedenih problema i pridonose, uz ostale faktore, onome što sugovornici kolokvijalno nazivaju „apatijom“ stanovnika i što rezultira određenom pasivnošću lokalne zajednice u rješavanju ovih i sličnih problema. To stoga usporava i rad na brendiranju vlastitih proizvoda kao što su masline ili maslinovo ulje, dok su u nekim drugim mjestima na otoku, primjerice Postirima, ove aktivnosti vrlo razvijene i aktivno se brendiraju različiti proizvodi te unaprjeđuju obrti (Tonković i Zlatar, 2014). Kada se govori o konkretnim turističkim lokacijama i atrakcijama u naselju i njihovoj promjeni od 2009. do 2019. (Tablica 6), može se primijetiti kako se u 2009. kao turističke atrakcije pojavljuju uglavnom prirodne lokacije, povijesni spomenici i kulturna baština koji su nedovoljno iskorišteni u turističkoj ponudi.

Tablica 6. Glavne turističke lokacije i atrakcije u Povljima u 2009. i 2019.

\begin{tabular}{|c|c|}
\hline 2009. - TURISTIČKE ATRAKCIJE & 2009. - LOKACIJE \\
\hline $\begin{array}{l}\text { Lijepo i mirno mjesto: „Sve što je vrijedilo } \\
\text { prije } 10 \text { godina ostaje i danas: mala turistič- } \\
\text { ka zagušenost, ljupko mjesto za miran od- } \\
\text { mor." (umirovljenik, povremeni stanovnik) }\end{array}$ & $\begin{array}{l}\text { Javna infrastruktura: „Postoji nebriga općine Selca za } \\
\text { turizam u Povljima te neodržavanje i propadanje obje- } \\
\text { kata koji bi uz malo uloženih sredstava donosili velike } \\
\text { prihode." (npr. škola) (umirovljenik, stalni stanovnik) } \\
\text { "Treba renovirati školu i tamo omogućiti organizira- } \\
\text { nje večeri poezije, koncerte, igrokaze." (profesorica, } \\
\text { sezonski stanovnik) }\end{array}$ \\
\hline
\end{tabular}




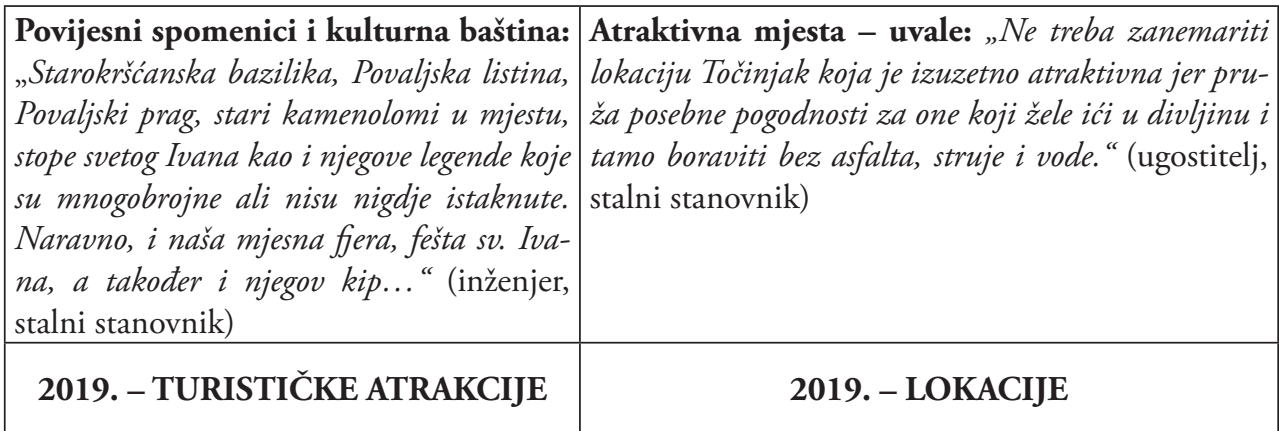

Zanemareni spomenici: „Imamo spome- Privatni smještaj: „Glavna ponuda za smještaj turinike koji nisu dovoljno izreklamirani i tu se sta, a ujedno i jedina je privatni smještaj i mislim da nije napravilo ništa, ima toliko stvari u Po- se prilično povećao broj ležaja u zadnjih 10 godina." vljima oko kojih nema nikakve promocije. " (inženjer, stalni stanovnik)

(nezavisni vijećnik općine i član turističkog vijeća, stalni stanovnik)

Zapuštenost mjesta: „Potencijal nije isko- Zatvoreni hotel Galeb i apartmansko naselje rišten. Nema ga tko iskorištavati ili planira- Punta: „Hotel Galeb, apartmansko naselje Punta, a ti, mjesto je tako reći napušteno." (pravnik, i općenito cijeli dio oko tog naselja, te Tičja luka, ne sezonski stanovnik)

mogu reći da se igdje interveniralo. "(inženjer, stalni stanovnik)

Također se spominju i neiskorištene lokacije hotela, apartmana, uvale Luke i škole, kao i propadanje istih objekata koji bi se uz malo truda mogli urediti i iskoristiti u turističke svrhe. U istraživanju 2019. spominju se nedovoljno promovirani spomenici i kulturnopovijesna baština te nepostojanje intervencija u razvoj mjesta, a samim time i njegovo stagniranje i čak propadanje iako se privatni smještaj proširuje kao jedini tip smještaja. U Tablici 7 navode se glavni akteri ili pokretači turizma u 2009. i 2019. Kao glavnog aktera u 2009. stanovnici ističu privatnu osobu koja je investirala i u svom vlasništvu imala najvažniju turističku imovinu mjesta (hotel i apartmane). Stanovnici-sugovornici smatraju da je lokalna zajednica bila aktivna samo u smislu pojedinačnih individualnih inicijativa koje ipak nisu zaživjele u dovoljnoj mjeri. Prisutan je i manjak turističkih kadrova koji bi poslove turizma vodili na način koji bi pridonio njegovu razvoju.

Tablica 7. Stavovi o glavnim akterima i potencijalnim pokretačima turizma u 2009. i 2019.

2009. - GLAVNI AKTERI U TURIZMU

Privatni investitor: „L. Vlahović, koja je otkupila hotel, imala je jednu od glavnih uloga u razvoju Povalja. Svatko tko je spreman uložiti svoj novac može biti jedan od pokretača u Povljima, i mislim da je ona $i$ dalje glavni akter u mjestu. " (profesorica, sezonski s.)

\section{9. - POTENCIJALNI POKRETAČI} TURIZMA

Strani investitori: „Glavni pokretač turizma u Povljima bio bi onaj tko bi kupio, renovirao $i$ otvorio hotel śto prije. Bilo bi poželjno da to bude neko domaci, ali ako bude stranac, nema veze, samo neka krene s tim jer to nam jedino nedostaje." (ugostitelj, stalni s.) 


\begin{tabular}{|c|c|}
\hline $\begin{array}{l}\text { Lokalna zajednica: „Na pojedincima je razvoj } \\
\text { turizma i on ovisi o privatnoj inicijativi koja } \\
\text { nažalost nije zaživjela. No, država bi se tako- } \\
\text { der trebala na neki način uključiti i financijski } \\
\text { potpomagati privatnike." (profesor, sezonski } \\
\text { stanovnik) }\end{array}$ & $\begin{array}{l}\text { Lokalne skupine mladih: "Glavni pokretač } \\
\text { turizma u Povljima ne može biti jedna osoba, } \\
\text { nego više njih. Konkretno mislim da će kroz koju } \\
\text { godinu stvari u Povljima krenuti na bolje, kada } \\
\text { se mladi i poduzetni ljudi vrate sa studija i smi- } \\
\text { jene stare i nezainteresirane sumještane na nekim } \\
\text { pozicijama." (inženjer, stalni stanovnik) }\end{array}$ \\
\hline \multicolumn{2}{|l|}{$\begin{array}{l}\text { Manjak turističkih kadrova: „Najveća slabost } \\
\text { je u nepostojanju pravih kadrova koji bi vodili } \\
\text { poslove turizma na pravi način." (ugostitelj, } \\
\text { stalni stanovnik) }\end{array}$} \\
\hline 2019. - GLAVNI AKTERI U TURIZMU & $\begin{array}{c}\text { 2019. - POTENCIJALNI POKRETAČI } \\
\text { TURIZMA }\end{array}$ \\
\hline $\begin{array}{l}\text { Lokalno stanovništvo: „Glavnu ulogu ima lo- } \\
\text { kalno stanovništvo i Općina, i to zadnjih 10-15 } \\
\text { godina. "(inženjer, stalni stanovnik) }\end{array}$ & $\begin{array}{l}\text { Lokalno stanovništvo: „Turizam će biti pokre- } \\
\text { nut kako treba, ako bude pokrenut organski, iz } \\
\text { samog mjesta." (pravnik, sezonski stanovnik) }\end{array}$ \\
\hline $\begin{array}{l}\text { Privatnici: „Ulogu u razvoju su imali spretniji } \\
\text { i imućniji pojedinci koji su obnavljajući svoje } \\
\text { posjede dobili poboljšanje općeg stanja u mjestu. } \\
\text { Mislim na pristupne ceste i komunalnu opre- } \\
\text { mljenost. Medutim, ulaskom u EU zajedno sa } \\
\text { svojim fondovima, mislim da će se vlastiti in- } \\
\text { teresi pojedinaca na vlasti smanjiti, a globalni } \\
\text { interesi mjesta kao cjeline povećati." (inženjer, } \\
\text { sezonski stanovnik) }\end{array}$ & $\begin{array}{l}\text { Domaći ili strani investitori: „Glavni pokre- } \\
\text { tač može biti bilo kakav investitor koji bi izgra- } \\
\text { dio neke sadržaje koji bi mogli privući ljude u } \\
\text { mjesto, a i zadržati postojeće. “ (inženjer, stalni } \\
\text { stanovnik) }\end{array}$ \\
\hline $\begin{array}{l}\text { Općina Selca: „Općina Selca i mjesna samou- } \\
\text { prava ostavljaju dojam da nešto rade (primjeri- } \\
\text { ce, vidikovac ponad sela), a ponuda restorana, } \\
\text { kafića i slastičarni je u privatnom sektoru. Ta- } \\
\text { kva konstelacija snaga nije se u } 10 \text { godina mije- } \\
\text { njala, koliko je meni poznato." (umirovljenik, } \\
\text { sezonski stanovnik) }\end{array}$ & $\begin{array}{l}\text { EU fondovi - strane investicije: „Za Povlja bi } \\
\text { odgovaralo da ostvari bolju popunjenost u pred } i \\
\text { postsezoni a za isto je potrebno pratiti natječaje } \\
\text { i sudjelovati ciljano u onim projektima s kojima } \\
\text { bi dobili sredstva iz EU fondova za razvoj tu- } \\
\text { rizma ne samo za sunce i more." (tour-agent, } \\
\text { sezonski stanovnik) }\end{array}$ \\
\hline
\end{tabular}

Tablica 8. Tip i reputacija turizma u 2009. i 2019.

\begin{tabular}{|c|c|}
\hline 2009. - REPUTACIJA TURIZMA & $\begin{array}{c}\text { 2009. - NAJPRISUTNIJI TIPOVI } \\
\text { TURIZMA }\end{array}$ \\
\hline $\begin{array}{l}\text { Mirno turističko mjesto: „Turisti su prezadovolj- } \\
\text { ni Povljima jer je mirno, ništa se spektakularno ne } \\
\text { dogada, što njima i odgovara, dobra je hrana, čisto } \\
\text { more. Ove je godine došlo mnogo turista i brali su } \\
\text { masline."(načelnik općine, stalni stanovnik) }\end{array}$ & $\begin{array}{l}\text { Obiteljski turizam: „Obiteljski je najprisutni- } \\
j i, \text { i to bez obzira radi li se o vlasnicima vikendi- } \\
\text { ca ili prolaznim turistima." (profesor, sezonski } \\
\text { stanovnik) }\end{array}$ \\
\hline
\end{tabular}




\begin{tabular}{|c|c|}
\hline $\begin{array}{l}\text { Nepromijenjena reputacija: „Mislim da je re- } \\
\text { putacija ostala ista. Turisti Povlja doživljavaju } \\
\text { kao mirno, toplo i ugodno mjesto za boravak, } \\
\text { zato i kupuju kuće i vikendice u Povljima... “ } \\
\text { (umirovljenik, stalni stanovnik) } \\
\text { Nedostatak turističkih sadržaja: „Ovdje ne } \\
\text { može ni doći gost koji ima mnogo novaca, jer ga } \\
\text { nema gdje potrošiti i nema kamo otići.“ (ugosti- } \\
\text { telj, stalni stanovnik) } \\
\text { Nezadovoljavajući turistički doživljaj: „Mi- } \\
\text { slim da turisti Povlja doživljavaju na način koji } \\
\text { nama ipak ne bi trebao odgovarati. U Povlja za- } \\
\text { dnjih nekoliko godina dolaze izrazito stari gosti } \\
\text { koji žele mir i spokoj, a mi bi trebali biti upravo } \\
\text { obrnuto - živi. “(inženjer, stalni stanovnik) }\end{array}$ & $\begin{array}{l}\text { Potencijali za spajanje masovnog i eko-turiz- } \\
\text { ma: „Bilo bi odlično da se nadopunjava eko-tu- } \\
\text { rizam i masovni turizam. Za eko-turizam mi } \\
\text { možemo ponuditi stoćarstvo koje je u centralnom } \\
\text { dijelu Brača, a u Povljima imamo masline. U } \\
\text { maslinicima se rade male kućice koje su pogodne } \\
\text { za robinzonski turizam. “(načelnik općine, stalni } \\
\text { stanovnik) } \\
\text { Stagnacija: „Stagnacija je počela već iza rata, } \\
\text { nakon privatizacije hotela kao glavnog turističkog } \\
\text { objekta. Eko-turizam je dobra varijanta, no nema } \\
\text { dovoljno sredstava za njegovu realizaciju i bila bi } \\
\text { potrebna neka nova snaga kako bi se eko-turizam, } \\
\text { kao i turizam općenito, realizirao. Ako se nešto ne } \\
\text { promijeni, svi će otići iz Povalja. Mi smo svi vé́ } \\
\text { stari. “ (ugostitelj, stalni stanovnik) }\end{array}$ \\
\hline 2019. - REPUTACIJA TURIZMA & $\begin{array}{c}\text { 2019. - NAJPRISUTNIJI TIPOVI } \\
\text { TURIZMA }\end{array}$ \\
\hline $\begin{array}{l}\text { Malo mjesto bez turističkih sadržaja: „U Pov- } \\
\text { lja dolaze nezahtjevni gosti, ne traže neke sadržaje } \\
\text { i mislim da su zadovoljni s onime što Povlja pru- } \\
\text { žaju, reputacija je ostala ista. “ (ugostitelj, sezon- } \\
\text { ski stanovnik) } \\
\text { Nedovoljno sadržaja za mlade: „Nema muzi- } \\
\text { ke, nema mjesta na koje se može otići i provodi- } \\
\text { ti vrijeme, sve se svelo na pojedince, tj. privatni } \\
\text { smještaj. (stolar, stalni stanovnik) } \\
\text { Nedovoljno sadržaja: „Treba istaknuti povijesne } \\
\text { lokalitete u edukativnom smjeru. Takoder, potreb- } \\
\text { no je pojačati broj i kvalitetu sadržaja, kako za } \\
\text { roditelje, tako i za djecu, u cilju privlačenja obi- } \\
\text { teljskog tipa turizma."(nezavisni vijećnik općine } \\
\text { i član turističkog vijeća, stalni stanovnik) } \\
\text { Čuvanje identiteta mjesta: „Važno je da se ne } \\
\text { ošteti identitet i kapaciteti mjesta, da se gradi i } \\
\text { mijenja onoliko koliko to dopuštaju gabariti i } \\
\text { stručna procjena. “ (ugostitelj, stalni stanovnik) }\end{array}$ & $\begin{array}{l}\text { Obiteljski turizam: "Tip turizma je ostao } \\
\text { obiteljski turizam i on je } i \text { dalje najprisutniji." } \\
\text { (umirovljenik, stalni stanovnik) } \\
\text { Potencijali za povezivanje poljoprivrede i } \\
\text { turizma (ekološkog ili ruralnog turizma): } \\
\text { „Mislim da u tom smjeru ne postoji ponuda jer } \\
\text { ne postoji značajno gospodarstvo u mjestu. Mi- } \\
\text { slim da jedna osoba radi neko eko / etno selo u } \\
\text { masliniku, možda je to vrhunac u dosegu ove } \\
\text { vrste turizma za Povlja. " (tour-agent, sezonski } \\
\text { stanovnik) }\end{array}$ \\
\hline
\end{tabular}

Potencijal se može vidjeti u mogućnostima ulaganja stranih investitora, ali i u mladima koji bi mogli razviti određene nove tipove turizma. U 2019. uz lokalno stanovništvo Povlja kao glavni akter u turizmu spominje se i općina Selca, no više u smislu formalnog ostavljanja dojma, nego stvarno vidljivih rezultata. I moguća strana ulaganja, primjerice iz fondova EU-a, također se smatraju korisnim pokretačem ponajviše u smislu popunjenosti predsezone i poslijesezone. 
Važno je naznačiti i kategorije tipa i reputacije turizma te način na koji su se oni mijenjali 2009. i 2019. (Tablica 8). Možemo primijetiti kako se reputacija turizma u posljednjih 10 godina nije znatno promijenila pa se zato uglavnom spominje zadovoljstvo turista mirom i nenapučenošću mjesta kao pozitivnim odrednicama, a nedostatak turističkih sadržaja negativnima.

U istraživanju 2019. sugovornici spominju i nepostojanje sadržaja za različite skupine stanovnika, pa tako i za mlade ali i nedovoljne mogućnosti za obiteljski tip turizma. Broj i kvaliteta sadržaja koji se tiču obiteljskog turizma trebali bi se povećati, iako se 2009. smatralo da je taj tip turizma najprisutniji. Također su, 2009. sugovornici spominjali i potencijal za spajanje masovnog i eko-turizma koji bi se mogli nadopunjavati u svojim elementima, primjerice povezanost ponude seoskih gospodarstava koji se bave stočarstvom i maslinarstvom s otvaranjem hotela. Poljoprivredna obilježja mjesta utječu na daljnji razvoj turizma, a budući da Povlja imaju povijest maslinarstva i maslinova ulja mogu se dodatno uklopiti u novi trend turističke ponude. Poticanje i razvijanje maslinarske proizvodnje bio bi važan i konstruktivan korak u daljnjem turističkom razvoju (Zlatar, 2010; Zlatar Gamberožić i Tonković, 2015).

Većina je sugovornika i ranije spominjala stagnaciju kao realan scenarij razvoja zbog nedovoljnih sredstava, ali i manjka društvenog kapitala koji nose razvojni akteri (pojedinci i lokalna zajednica), a koji bi zajedno trebali pokrenuti ključne turističke djelatnosti.

Sugovornici 2019. kao najprisutniji scenarij razvoja naselja naglašavaju obiteljski turizam, unatoč njegovim nedostacima ili ograničenjima, ${ }^{4}$ ali ističu i nedovoljnu iskorištenost potencijala za razvoj ruralnog ili eko-turizma.

Ako govorimo o daljnjoj perspektivi razvoja Povalja, istraživanje provedeno 2009. ukazalo je na tri moguća tipa razvoja kao tri scenarija za turistički razvoj Povalja.

1. Eko-turizam5 : autentična turistička ponuda koja vodi računa o ekološkim standardima i prirodnim ljepotama mjesta;

2. Masovni turizam ${ }^{6}$ : otvaranje hotela i apartmanskog naselja i škole koja bi omogućila da se dio stanovništva vrati, kao i da se privuče nove stanovnike;

3. Stagnacija: scenarij koji se pokazao najvjerojatnijim i najnepoželjnijim.

\footnotetext{
4 Nedostaci koje spominju sugovornici tiču se uglavnom nerazvijene ponude obiteljskog turizma kao što su nedovoljno sadržaja za djecu i mlade, nedovoljna ponuda restorana i sadržaja za zabavu poput noćnih klubova ili sportskih i kulturnih sadržaja.

5 Pod eko- ili agroturizmom podrazumijevamo standard ruralnog razvoja kroz koncept održivog razvoja, tj. očuvanje ekoloških, bioloških i kulturnih raznolikosti. U tom smislu Povlja bi mogla predstavljati jedan ruralni resurs netaknute prirode koji bi slijedili prikladni sadržaji poput autohtone prehrane, organizacije izleta, gradnje ruralnih parkova i naselja uz uzimanje u obzir prostornih kapaciteta mjesta i njegovog izvornog identiteta (Zlatar, 2010:260).

6 Pod kojim se podrazumijeva uglavnom oblik turizma u kojem je zastupljen velik broj ljudi, organizirana putovanja i to često pod vodstvom agencije. „Karakteristike su ovog oblika turizma veliki broj svih slojeva stanovništva i vremenska koncentracija turističkog prometa na razdoblje godišnjih odmora, osobito ljeti“ (Kušen, 2001:3).
} 
Uz stagnaciju se, od spomenuta tri tipa razvoja turizma, u 2009. također ukazuje i na potencijal održivog / ruralnog / ekoturizma. Djelatnosti vezane uz proizvodnju maslinovog ulja i vina te ribolova bile bi idealan smjer za razvoj agroturizma i trebalo bi ih razvijati, tvrde sugovornici u istraživanju 2019. Obiteljski turizam iako najprisutniji smatra se nedovoljno razvijenim, ali i dalje optimalnim za mjesto. Ponajprije trebalo bi poraditi na istaknutim problemima rješavanje kojih pomoglo bi daljnji razvoj obiteljskog tipa turizma (podizanje kvalitete mjesta i rješavanja spomenutih infrastrukturnih problema, poput gospodarenja otpadom, podizanja kvalitete plaža i gastronomske ponude, te rješavanja problema parkirališnih mjesta). Također javljaju se i ideje za nove tipove turizma kao što su sportski ili zdravstveni turizam koje se i inače u različitim strateškim konceptima smatraju poželjnima. „Hrvatska obala skupa s otocima na temelju prirodnih karakteristika ima dobre uvjete za plivačke aktivnosti i aktivnosti skijanja na vodi, jedrenje na dasci, ronjenje, nautiku i jedrenje na raznim plovilima, a u zimskim mjesecima ima dobre uvjete za razvoj zdravstvenog turizma uz specifične oblike sportsko - rekreacijskih aktivnosti“" (Vlada RH, 2013:27).

Dobri primjeri u primjeni spomenutih aktivnosti mogu se vidjeti u Postirima i u Bolu koji se također usmjeravaju prema sportskom tipu turizma ${ }^{7}$.

\subsection{Ideje za daljnje poboljšanje turizma Povalja}

Dobivene rezultate prikupljene intervjuima može se grupirati u četiri kategorije, a većinom su to ideje o revitalizaciji mjesta u turističkom smislu kroz organizirane izlete $s$ različitim sadržajima i razgledavanje otoka i mjesnih povijesno-kulturnih lokaliteta i spomenika, ali i krajolika kojima se ističe očuvanost specifične i autentične prirodne i kulturne baštine. Spajanjem poljoprivrede i turizma i uređenjem infrastrukture, ali i poticanjem razvoja sportskog turizma otvara se put prema različitim, ali vrlo kompatibilnim aspektima za održiv model razvoja mjesta. U tom se smislu ukazuje na alternativne i održive, ali prije svega dugoročne i odgovorne oblike turizma na otocima koji su jedini mogući put razvoja ovako osjetljivih socioekonomskih zajednica.

Prva kategorija odgovora odnosi se na lokalnu inicijativu koja bi mogla počivati na razgledavanju mjesnog krajolika koji je još vrlo očuvan i autentičan što nudi vrlo jedinstven doživljaj i u turističkom smislu. Takav je turizam danas atraktivan i prihvaćen posebno zato jer ističe kompatibilnost s prirodnim i ostalim obilježjima lokalne sredine. Te i slične poduzetničke akcije i inicijative bile bi važne jer mještani mogu učiniti mjesto, ali i ovaj dio otoka privlačnijim te ekonomski i socijalno snažnijim. I Zakon o otocima (NN 116/18, 73/20) isto se uvelike oslanja na jačanje i promoviranje socijalne uključenosti, edukacije i participacije građana. Cjelovitost turističke ponude može se spojiti $s$ višestoljetnom kultiviranom zemljoradnjom, ribarstvom i pomorskom tradicijom Povalja. Takav spoj djelatnosti navodi sugovornik u sljedećoj izjavi:

\footnotetext{
7 „Ronilački centri nude sve, od početničkih tečajeva i tečajeva za djecu do naprednih tečajeva te poludnevne, cjelodnevne i noćne ronilačke izlete; zahvaljujući stalnom bočnom vjetru koji puše duž bračko-hvarskog kanala, Bol je omiljena destinacija za surfere iz Europe i dalje, a sezona započinje u svibnju i traje do kraja rujna" (Zurak, 2016:28).
} 
„Treba istaknuti povijesne lokalitete, ali u edukativnom smjeru. Pojačati broj kulturnih sadržaja, kako za djecu, tako i za roditelje. "(nezavisni vijećnik općine i član turističkog vijeća, stalni stanovnik)

Druga se kategorija odnosi na razvojne programe u ekoturizmu ili agroturizmu koji podrazumijevaju dobro koncipirane i uređene kuće, zelene vrtove, uredne javne površine, vlastitu proizvodnju ekološke hrane koja udovoljava ekološkim kriterijima i također se spominju u Zakonu o otocima (NN 116/18, 73/20) kroz „diversificiranje otočnog gospodarstva iskorištavanjem posebnosti otoka u stvaranju novih i inovativnih lokalnih djelatnosti“. I autor Vlahović (2007) upozorava na maslinarsku proizvodnju i posebnost ovakvog krajolika (kraj bogat aromatičnim travama, poznat po burama koje donose sol $s$ mora) pri čemu se Povlja mogu prepoznati u afirmaciji turističko-maslinarske sredine. Ovakve se ideje mogu primijetiti u sljedećem odgovoru:

„Zadnjih nekoliko godina postoje naznake širenja ruralnog turizma koji je vezan za obradene $i$ sređene plantaže maslina s pratećim objektima. Po mojem mišljenju, veza između poljoprivrede i turizma u smislu stvaranja ruralnog turizma postoji, a taj se tip turizma tek pojavljuje u nekakvim naznakama." (sudski savjetnik, sezonski stanovnik)

Sljedeća se kategorija odgovora odnosi na infrastrukturno uređenje mjesta. U Strateškom razvojnom programu općine Selca (2015) spominje se rješenje važne lokacije za organiziranje mjesnog parkirališta s tržnicom koju su sugovornici redovito navodili. Također postoji plan da se zgrada bivše škole (Slika 4) dovede u funkciju kao kulturno-promotivni i uslužni objekt jer stoji prazna i zapuštena, ali i da se osiguraju odgovarajuća privezišta za dolazak većeg broja jahti i drugih brodova. Planira se i javna rasvjeta, uređenje većeg broja plaža i osiguranje brodske (katamaranske) linije zbog poboljšanja prometnih veza. Strateški razvojni program općine Selca spominje i Idejno rješenje (projekt) za cestu Povlja-Pučišća (Općina Selca, 2015).

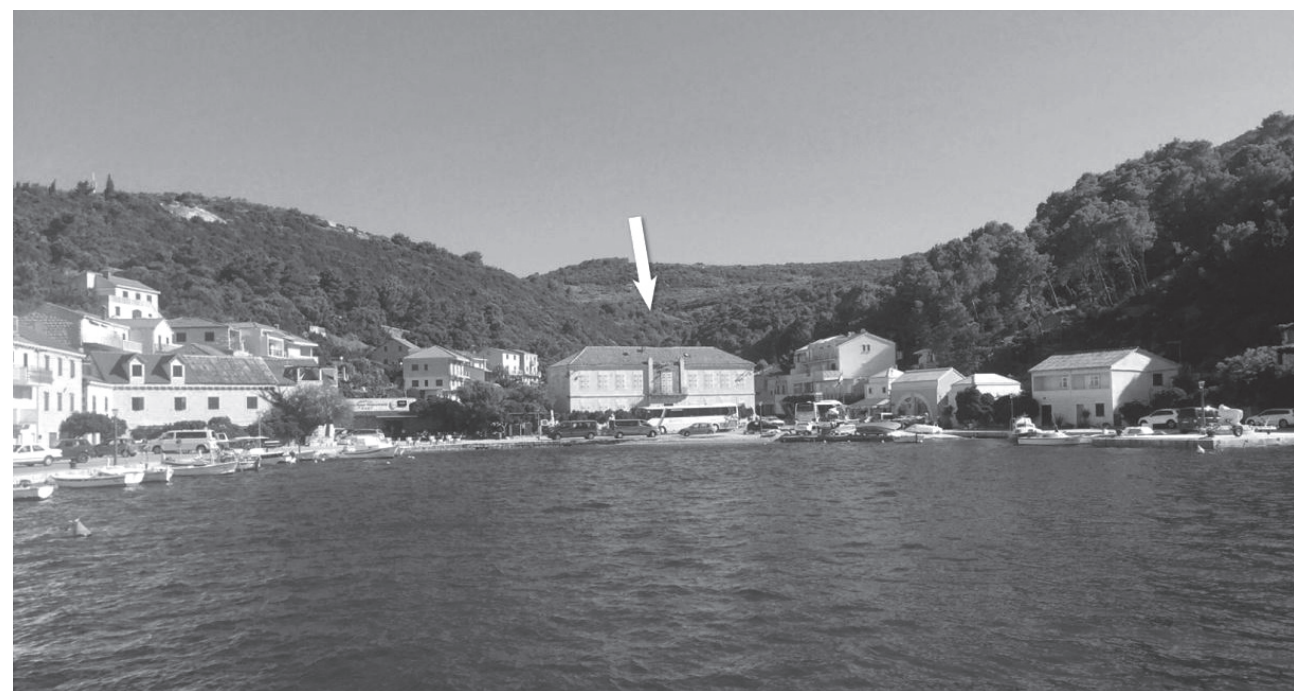

Slika 4. Zatvorena mjesna škola (fotografja autorica, 2019) 
Strategija također ističe kako „razvoj turizma obećava stanoviti prosperitet, jer duboka i razgranata povaljska luka privlači ljepotom prirode i kupanjem u brojnim manjim uvalama i onima izvan nje, kao što su Smokvica, Tičja luka, Tatinja, Travna, Konopikova i druge" (Općina Selca, 2015:3). Povaljska riva kao turistička promenada (lungo mare) i prostor oko rive pješačke su zone. Riva je krajem 1999. proširena i učvršćena kamenim rubom u ukupnoj dužini od 180 metara, odgovarajuće rasvijetljena i s nekoliko ormarića osposobljena za prihvat jahti. Riva kao glavna šetnica turista ljeti ne smije biti opterećena kretanjem automobila i drugih vozila. S obzirom na to da se Povlja nalaze u neposrednoj blizini Makarske rivijere (jake turističke zone), dnevno bi mogla primati veći broj izletničkih brodova, kao i gostiju iz drugih bračkih mjesta. Strateški razvojni program općine Selca obuhvaća izgradnju cesta, šetnice, biciklističke staze, oznake za selačko ulje, uređenje zadružnog doma. Od svih navedenih planova ostvaren je za sada samo plan uređenja zadružnog doma. Također su planirani, no dosad nisu ostvareni:

- rekonstrukcija i izgradnja luke otvorene za javni promet u Povljima;

- uređenje i tematiziranje plaža Sumartin, Povlja, Tičja Luka, Santa Barbara Puntinak;

- izgradnja vodoopskrbe i kanalizacije za kvartove u Sumartinu i Povljima;

- izgradnja tržnice i ribarnice (Općina Selca, 2015).

U navedenom smjeru idu i razmišljanja sugovornika:

„Važno je omoguciti parking za automobile kako riva ne bi bila pretrpana, poboljšati jako lošu prometnu regulativu, kažnjavati komunalne prekršaje, osloboditi most od mreža i ostale ribarske opreme koja je neuredno razbacana... potrebno je infrastrukturno urediti mjesto." (inženjer poštanskog prometa, stalni stanovnik)

I u ranijem istraživanju 2009. pokazane su neke od najvažnijih odrednica koje mogu biti ispunjene, a u skladu su s navedenim idejama. Prema Strategiji Europa 2020 (Europska komisija, 2010) iznosi se, primjerice, vizija europske socijalne tržišne ekonomije tijekom idućeg desetljeća koja počiva na tri međusobno povezana područja vrlo važna i spomenuta i na ovom lokalnom primjeru: a) pametan rast (kojim se potiču znanje, inovacije, obrazovanje i digitalno društvo); b) održiv rast (kojim će lokalna proizvodnja postati odgovornija u iskorištavanju resursa, uz istovremeno povećanje konkurentnosti) i c) uključiv rast (povećanjem sudjelovanja na tržištu rada, stjecanjem novih vještina te borbom protiv siromaštva) (Europska komisija, 2010). U spomenutim su idejama sadržani i programi i projekti koji se planiraju za Povlja, ali i same ideje lokalnih stanovnika koji žele povećanje participacije i veću aktivnost lokalne zajednice u pravcu održivog i dugoročno sačuvanog mjesta. Današnji modeli i novi tipovi turizma, uključujući i masovni turizam ili specijalizirani turizam zahtijevaju pažljivo planiranje kako bi se osiguralo da je razvoj turizma integrirani dio razvojne održive strategije (Bramwell, 2004), a takvi, novi modeli, spadaju pod četvrtu kategoriju revitalizacije mjesta koju podržava sljedeća izjava:

„Za najmlade treba organizirati školu plivanja ili vaterpola. Za tinejdžere obavezno treba prirectivati zabave sa živom muzikom u terminima od 22 sata do jutra, ali na lokacijama malo udaljenijim od sela (Punta, Dramotinje ili Luke). Za malo starije mogla bi se organizirati natjecanja u sportovima." (inženjer, stalni stanovnik) 
Prayag (2011) upozorava i na to da razvoj turizma na otocima mora biti integriran u ciljeve poboljšavanja kvalitete života. Podizanje kvalitete života otočana svakako bi trebao biti ključni cilj, kako u smislu smanjenja depopulacijskih procesa, tako i u cilju turističkog razvoja adekvatnog i prikladnog za svako pojedino mjesto.

\section{RASPRAVA I ZAKLJUČCI: MOGUĆNOSTI REVITALIZACIJE MJESTA POVLJA}

Prema dobivenim podacima iz intervjua s lokalnim stanovnicima može se zaključiti kako se nije pokazala značajna razlika u promišljanjima o razvoju naselja između sezonskih i stalnih stanovnika osim u smislu postojanja većeg optimizma kod sezonskih stanovnika-sugovornika. Takvo je razmišljanje povremenih ili sezonskih stanovnika i očekivano jer se nalaze izvan svakodnevnog života u lokalnoj sredini većim dijelom godine te su stoga nerijetko i manje kritični i manjih očekivanja. Međutim, sezonski stanovnici u većoj mjeri primjećuju i negativne i pozitivne promjene, primjerice, izgradnju novih privatnih smještajnih kapaciteta ili pojedinačni angažman oko spajanja djelatnosti poljoprivrede i turizma, ali i proizvodnju veće količine otpada, nečistoću plaža, opću stagnaciju i sl. Sezonski su stanovnici također skloniji tražiti rješenja koja su se stalnim stanovnicima u nekom trenutku već učinila nedjelotvornima. Osim navedenih razlika, generalno i stalni i povremeni stanovnici na sličan način procjenjuju pozitivne i negativne dimenzije razvoja naselja, kao i scenarije razvoja mjesta i razvoja turizma.

Komparacija dvaju istraživanja provedenih u razmaku od desetljeća (2009.-2019.) potvrđuju razlike u odgovorima sugovornika. Prvenstveno uočava se veće nezadovoljstvo situacijom jer je prisutan i veći pesimizam 2019. i to u pogledu cjelokupne situacije u naselju. Dok se 2009. godine dio stanovništva oslanjao na ideju radne snage koja bi se vraćanjem u naselje počela na ozbiljan način baviti turizmom, u 2019. više se problematiziralo (ne)postojanje ili izostanak akcija i aktivnosti prvo Općine Selca te zatim i oslanjanje na potrebu prikupljanja sredstava iz različitih Europskih fondova. Strani investitori sada postaju prihvatljiva varijanta kao i bilo koja investicija privatnih aktera, uglavnom kako bi se omogućilo pokretanje s točke stagnacije koja je u ovih deset godina konstanta u perspektivi naselja.

U istraživanju 2009. navedene su tri opcije, tj. tri moguća scenarija za razvoj Povalja: masovni turizam, agro ili ekoturizam te stagnacija. Većina se sugovornika slaže kako je u proteklih deset godina nastupila stagnacija pa čak i nazadovanje u odnosu na prethodno istraživanje. To potvrđuje i izraziti pesimizam zbog neodrađenih projekata: nije došlo do otvaranja hotela ili apartmanskog naselja, nije otvorena škola, kao niti neki manje zahtjevni projekti poput uređenja plaža ili uvala za poboljšanja turističke ponude. Godinama su ostali neriješeni i stari ekološki problemi, primjerice potonuće broda u središtu mjesta koji je tek krajem 2019. uklonjen s morskog dna. Važno je naglasiti i da svi zapušteni objekti: hotel, škola i spomenuti brod, osim što predstavljaju ekološku prijetnju doprinose i socio-kulturnoj, ekonomskoj te estetskoj degradaciji mjesta. 
Zapuštenost tih objekata može se dovesti u vezu s neatraktivnim ili odbijajućim faktorima koji mogu utjecati na ukupnu procjenu kvalitete boravka u Povljima ili čak potencijalno odvratiti turiste od povratka u mjesto. Reputacija se turizma kao djelatnosti također pogoršala pa tako sugovornici upozoravaju na mnoge nove probleme koji su vidljivi iz perspektive turista, kao što su rast onečišćenja mjesta, nepovezanost ili vrlo slaba povezanost poljoprivrede i turizma, te neuređenost plaža.

$\mathrm{Na}$ temelju promišljanja sugovornika potvrđena je hipoteza rada da je stanje u turističkom razvoju Povalja utvrđeno istraživanjem 2019. nešto lošije nego prije deset godina. To je dijelom i očekivano s obzirom na neaktivnost svih potencijalnih aktera uključenih u razvoj mjesta, odnosno vrlo malu uključenost aktera iz lokalne vlasti i samih građana. Lokalna vlast je u međuvremenu vrlo malo učinila na promjeni stanja i doživljaju samog mjesta pa se već postojećim problemima pripojio i niz novih. Takve se nalaze često može naći i u nekim drugim sličnim istraživanjima posebno malih otočnih zajednica (Klempić Bogadi i Podgorelec, 2011; Nakićen i Čuka, 2016) koji pokazuju da iako kod domaćih stanovnika postoji relativna sklonost i pripadnost otočkom načinu življenja, postoje i brojni nedostaci kojima se ostanak na otoku otežava. Stoga je glavni cilj turističkog razvoja hrvatskih otoka poboljšavanje kvalitete života i sprječavanje depopulacije, te traženje ravnoteže između ključnih dimenzija održivosti: ekološke, ekonomske i socio-kulturne (Tonković i Zlatar, 2014) na koje se upozorava i u prethodnim istraživanjima, a koje su usko povezane s top down i bottom up pristupom, odnosno inicijativama koje dolaze iz lokalne zajednice $s$ onima koje dolaze iz viših razina vlasti (općine ili države). $\mathrm{U}$ tom smislu ravnoteža treba biti usmjerena na razvoj lokalne inicijative u integraciji s državnim inicijativama. Pritom mora biti ključno jačanje lokalne zajednice i educiranje stanovništva za razvoj odgovornog turizma (Tonković i Zlatar, 2014). Stoga daljnji razvoj otoka mora biti percipiran kroz povezanost tradicionalnog i autentičnog načina života na otoku s novim razvojnim trendovima kako bi se kao takav mogao održati na dugoročno prihvatljiv način. Tu je iznimno važan faktor prometna povezanost pa su uspostavljanje trajektne veze i izgradnja cesta nužni kako za samo naselje tako i za otok Brač. Na spoju tradicionalnih i novih razvojnih trendova, kao i na prometnoj povezanosti te ekološkoj, ekonomskoj i socijalnoj ravnoteži leže dobri temelji za razvoj. Oni se mogu vidjeti i u turizmu, ribarstvu, poljoprivredi, brodogradnji, kamenolomima, a pomiču se od koncentrirane na mješovitu ekonomiju (Montana, 1994; Mišetić, 2006). Stvaranje prepoznatljivog turističkog identiteta također je važna odrednica razvoja turizma na otocima kao specifičnim lokalnim zajednicama. Povlja u ovom smislu, iako trenutno u stagnirajućem stadiju razvoja, još uvijek imaju mogućnost razvoja prema održivosti i agroturizmu koji bi u kombinaciji s obiteljskim turizmom za njih bio i najbolje rješenje te osigurao razvoj temeljeći se na mješovitoj ekonomiji. Nosivost (carrying capacity) svakog mjesta također podrazumijeva i participaciju lokalne zajednice u procesu donošenja odluka kao jednu od važnijih dimenzija uključenosti stanovništva i pokretanja lokalnih akcija. Svaka lokalna zajednica ima svoje kapacitete prema kojima se mora orijentirati i koje mora poštivati kako bi se implementirale kvalitetne političke odluke ovisne o specifičnim mogućnostima pojedinog otoka i naselja na njemu. $\mathrm{Na}$ taj 
se način može uvažiti i ovdje spomenute specifičnosti naselja Povlja i važnost promišljanja njegovih stanovnika. Na primjeru provedenog istraživanja mogu se iščitati budući orijentiri i smjernice istraživanja otočne problematike, specifične i osjetljive na neodržive načine razvoja. No, $s$ druge strane otočna naselja imaju i velike mogućnosti postati održiva i odgovorna te čuvati lokalne posebnosti, ali samo na način uzimanja u obzir spomenutih razvojnih preduvjeta.

\section{LITERATURA}

Aguiló, E., Alegre, J. i Sard, M. (2005). The Persistence of the Sun and Sand Tourism Model. Tourism Management, 26: 219-231.

Bramwell, B. (2004). Mass Tourism, Diversification and Sustainability in Southern Europe's Coastal Regions. U: Bramwell, B. (ur.), Coastal Mass Tourism: Diversification and Sustainable Development in Southern Europe (str. 1-31). Clevedon: Channel View Publications.

Defilippis, J. (2001). O gospodarskom razvoju hrvatskih otoka. Sociologija Sela, 39(14): 83- 97.

Delibašić, T. i Vidučić, V. (2003). Međuovisnost putničkoga morskog brodarstva i turizma u Hrvatskoj. Zbornik radova - Sveučilište Rijeka, ekonomski fakultet u Rijeci, 21(2): 77- 92.

Dodds, R. (2007). Sustainable Tourism Policy - Rejuvenation or a Critical Strategic Initiative. Anatolia: An International Journal of Tourism and Hospitality Research, 18(2): 277- 298.

Državni zavod za statistiku (DZS) (2011). Popis stanovništva 2001.godine. Popis stanovništva, kućanstava i stanova 2011. Prvi rezultati po naseljima. Statistička izvjeśća, 1441/2011. URL: https://www.dzs.hr/Hrv_Eng/publication/2011/SI-1441. $\operatorname{pdf}(09.04 .2020$.)

Državni zavod za statistiku (DZS) (2019). Turizam u 2018. Statistička izvješća, 1639/2019. URL: https://www.dzs.hr/Hrv_Eng/publication/2019/SI-1639.pdf (13.05.2020.)

Europska komisija (2010). Europa 2020. Europska strategija za pametan, održiv i uključiv rast. Priopćenje komisije, COM (2010) 2020, Bruxelles, 3. ožujka 2010. URL: https://strukturnifondovi.hr/wp-content/uploads/2017/03/Strategija-EUROPA-2020.- hr.pdf (28.04.2020.)

Fabjanović, Đ. (1991). Promjene u dinamici i strukturi stanovništva otoka Brača. Hrvatski geografski glasnik, 53(1): 75-94.

Faričić, J., Graovac, V. i Čuka, A. (2010). Mali hrvatski otoci - radno-rezidencijalni prostor i/ili prostor odmora i rekreacije, Geoadria, 15(1): 145-185.

Farsari, Y., Butler, R. i Prastacos, P. (2007). Sustainable Tourism Policy for Mediterranean Destinations: Issues and Interrelationships. International Journal of Tourism Policy, 1(1): 58-78. 
Friganović, M. A. (2001). O demografskoj problematici hrvatskih otoka na Jadranu. Sociologija sela, 39(1-4): 37-59.

Graovac, V. (2004). Otoci na rubu izumiranja - primjer zadarskih otoka. Geoadria, 9(2): 183- 210.

Klempić Bogadi, S. i Podgorelec, S. (2011). Sociogeografske promjene u malim otočnim zajednicama - primjer otoka Zlarina. Geoadria, 16(2): 189-209.

Kušen, E. (2001). Turizam i prostor - klasifikacija turističkih atrakcija. Prostor, 9(1): $1-13$.

Kuveždić, H. (1999). Razvoj i suvremeno stanje turizma na otoku Braču. Acta Geographica Croatica, 34(1): 127-149

Lajić, I., Podgorelec, S. i Babić, D. (2001). Otoci - ostati ili otići? Studija o dnevnoj cirkulaciji sa šibenskih otoka. Zagreb: Institut za migracije i narodnosti.

Lajić, I. i Mišetić, R. (2013a). Osnovni demografski procesi na Kvarnerskim otocima od 1991. do 2011. godine. Geoadria, 18(1): 71-92.

Lajić, I. i Mišetić, R. (2013b). Demografske promjene na hrvatskim otocima na početku 21. stoljeća. Migracijske i etničke teme, 29(2): 169-199.

Mackelworth, P. C. i Carić, H. (2010). Gatekeepers of Island Communities: Exploring the Pillars of Sustainable Development. Environmental Development and Sustainability, 12(4): 463-480.

Magaš, D. (1996). Hrvatski otoci - osnovna geografska i geopolitička obilježja. Geoadria, 1(1): 5-16.

Martinić Jerčić, L. (2018). Razvoj naselja otoka Brača. Završni rad. Zagreb: Prirodoslovno- matematički fakultet Sveučilišta u Zagrebu, Geografski odsjek.

Mišetić, R. (2006). Neka sociodemografska obilježja stanovnišstva obalnih naselja. Društvena istraživanja, 15(1-2): 97-114.

Mišetić, R. (2010). Srednja Dalmacija: prostor diferenciranoga demografskog razvitka (1961.- 2001.). Migracijske i etničke teme, 26(3): 297-319.

Montana, M. (1994). Ekonomija malih razmjera u otočnom razvoju. Društvena istraživanja, 3(4-5): 531-546.

Nakićen, J. i Čuka, A. (2016). Demografski razvoj otoka Brača i sklonost otočana iseljavanju. Migracijske i etničke teme, 32(3): 319-351.

Općina Selca (2015). Strateški razvojni program općine Selca za razdoblje 2015.-2020. URL: https://www.selca.hr/pdf/opcinski-nacelnik/2017/Strategija\%20razvoja\%20 Opcine\%20Selca\%20-\%202015\%20- 2020.pdf (12.02.2020.)

Općina Selca (2021). Stanovništvo - Stanovništvo Brača (Općine). URL: http://www. selca.hr/stanovnistvo.php\#.YE8oCVVKiUk (16.03.2021.)

Petrić, L. i Pranić, L. (2010). The Attitudes of the Island Local Community Towards Sustainable Tourism Development - the Case of Stari Grad, Island Hvar. U: Favro, S. i Brebbia, C. A. (ur.), Island sustainability (str. 77-88). Southampton: WIT Press. Podgorelec, S. i Klempić-Bogadi, S. (2013). Gradovi potopili škoje - promjene u malim otočnim zajednicama. Zagreb: Institut za migracije i narodnosti. 
Prayag, G. (2011). Rejuvenating Paradise: Changing Products, Changing Markets and Changing Visitor Behaviour in Mauritius. U: Carlsen, J. i Butler, R. (ur.), Island Tourism: Sustainable Perspectives (str. 157-170). Wallingford: CAB International.

Radinović, S., Par, V. i Gugić, J. (2004). Socioekonomski procesi u obiteljskim poljoprivrednim gospodarstvima Dalmacije. Društvena istraživanja, 13(4-5): 825-842.

Ruspini, E. (1999). Longitudinal Research and the Analysis of Social Change. Quality \& Quantity 33(3): 219-227

Ruzmarin: Postira - Brač (2020). Info \& map. URL: http://www.ruzmarin.com/UK/ info_uk.html (15.03.2020.)

Starc, N. (1994). Razvoj, održivost i ocjena ulagačkih pothvata. U: Klarić, Z. (ur.), Prema održivom razvitku turizma u Hrvatskoj (str. 67-81). Zagreb: Institut za turizam.

Starc, N. (2001). Upravljanje razvojem otoka. Sociologija sela 39(1-4): 15-36.

Starc, N. i Stubbs, P. (2007). Islander vs. the state? Participation in Island Development Programmes in Croatia. 47 Congress of the European Regional Science Association: Local governance and sustainable development. Pariz, 29. kolovoza - 2. rujna 2007.

Stiperski, Z., Malić, A. i Kovačević, D. (2001). Međuzavisnost dostupnosti, gospodarstva i revitalizacije hrvatskih otoka. Sociologija sela, 39(1-4): 153-168.

Šimunović, I. (1994). Otoci u svjetlu socio-ekonomskih kretanja. Društvena istraživanja, 3(4- 5): 451-466.

Šimunović, I. (2007). Živjeti na otoku. U: Šimunović, I. (ur.), Brački zbornik br. 22 (str. 455- 467). Split: Naklada Bošković.

Šulc, I. (2014). Turistički razvoj i stagnacija otoka Korčule u modelu razvojnog ciklusa turističkih područja. Hrvatski geografski glasnik, 76(2): 61-84

Tonković. Ž. i Zlatar, J. (2014). Sustainable Development in Island Communities: The Case of Postira. European Countryside, 6(3): 254-269.

Turistička zajednica općine Selca (2020). Privatna komunikacija s autoricama putem elektroničke pošte, 12. veljače 2020.

Vlada Republike Hrvatske (2013). Prijedlog strategije razvoja turizma Republike $\mathrm{Hr}$ vatske do 2020. godine. URL: https://mint.gov.hr/UserDocsImages/dokumenti/ Strategija- turizam-2020-veljaca2013.pdf (15.05.2020.)

Vlahović, D. (2007). Turizam u Povljima. U: Ostojić Petrov, M. (ur.), Povaljski zbornik (str. 20-37). Split: Naklada Bošković.

Wiles Howard, M. (2001). Održivi turizam na otocima Old Providence i Santa Catalina: Analiza prihvatnog kapaciteta. Turizam, 49(4): 341-354.

Zakon o otocima. Narodne novine, 116/18, 73/20.

Zlatar, J. (2010). Odrednice turističke djelatnosti u smjeru održivog razvoja - primjer mjesta Povlja na otoku Braču. Sociologija i prostor, 48(2): 247-272.

Zlatar Gamberožić, J. i Tonković, Ž. (2015). From Mass Tourism to Sustainable Tourism: A Comparative Case Study of the Island of Brač. Socijalna ekologija, 24(2-3): $85-102$.

Zurak, J. (2016). Aktivan turizam na hrvatskoj obali i otocima. Završni rad. Zadar: Odjel za turizam i komunikacijske znanosti, Sveučilište u Zadru. 


\title{
COMPARISON OF TOURISM DEVELOPMENT SCENARIOS OF POVLJA ON THE ISLAND OF BRAČ IN 2009 AND 2019

\author{
Jelena Zlatar Gamberožić and Anđelina Svirčić Gotovac
}

\begin{abstract}
Social and spatial transformations in Croatia are occurring in the cities and villages, both on the mainland and the islands. They are governed by the interests of various social actors, while the interventions cause changes in both the social structure and the physical spaces. The islands are particularly challenging as the negative demographic trends of depopulation and population loss create additional difficulties for initiating future development and making positive changes. This is especially true for small islands and small settlements, such as Povlja on the island of Brač. This research presents a case study as a longitudinal comparative analysis of this place and its changes as recorded in the studies conducted in 2009 and 2019. The study aims to compare whether the potential tourism development scenarios of Povlja in 2009 (mass tourism, sustainable tourism, and stagnation) have changed during this period, especially with regards to the social and economic situation. The method of semi-structured interviews with permanent and temporary (seasonal) residents of Povlja was used to gain insight into their views on the current and potential tourism development, as well as to compare the results between the 2009 and 2019 studies. The 2019 research shows that the place hasn't made any progress in the tourist or economic sense, and that among all possible scenarios, the most dominant is stagnation, which eventually leads to decline.
\end{abstract}

Keywords: small island settlements, tourism development scenarios, tourism, Povlja, Brač

\section{EIN VERGLEICH VON SZENARIEN DER TOURISTISCHEN ENTWICKLUNG VON POVLJA AUF DER INSEL BRAČ 2009 UND 2019}

\author{
Jelena Zlatar Gamberožić und Anđelina Svirčić Gotovac
}

\section{Zusammenfassung}

Sozialräumliche Transformationen in Kroatien umfassen Städte und Dörfer, sowohl auf dem Festland als auch auf den Inseln. Sie werden durch Interessen verschiedener sozialen Akteure verursacht und dabei entstehen Änderungen der sozialen Struktur und der Umwelt. Auf den Inseln laufen negative demografische Prozesse ab, die Einwohnerzahl sinkt und es ist zusätzlich schwierig, die Entwicklung anzukurbeln oder einen positiven Wandel zu ermöglichen. Gerade die kleinsten Inseln und kleine Siedlungen ragen besonders heraus, wie zum Beispiel die Siedlung Povlja auf Brač. In der Arbeit zeigen wir eine Fallstudie in Form einer vergleichenden longitudinalen Analyse dieses Ortes und die, in der im Zeitraum von zehn Jahren (2009 und 2019) durchgeführten Forschung, sichtbaren Änderungen. Das Forschungsziel ist es zu vergleichen, ob sich die möglichen touristischen Szenarien für Povlja aus dem Jahr 2009 (Massentourismus, nachhaltiger Tourismus und Stagnation) in diesem Zeitraum hinsichtlich der sozialen und ökonomischen Lage geändert haben. Mit Hilfe der Methode der halbstrukturierten Interviews mit ständigen und saisonalen Einwohnern von Povlja wurde erfragt, wie die Einwohner über die momentane und die potentielle Entwicklung des Ortes denken, und ob die Forschung aus dem Jahr 2009 mit Forschungsresultaten aus dem Jahr 2019 verglichen werden kann. Die Forschung aus dem Jahr 2019 hat gezeigt, dass der Ort weder im touristischen noch im ökonomischen Sinne einen Fortschritt gemacht hat, und dass von den angebotenen Szenarien am meisten die Stagnation mit einem Trend zum Rückgang präsent ist.

Schlüsselwörter: kleinere Inselsiedlungen, Szenarien der touristischenn Entwicklung, Tourismus, Povlja, Brač 